\title{
Bitch-Goddess: The Revolutionary Power against Tyrannical Patriarchy
}

\author{
M. K. S. S. Gunarathne \\ Department of Accounting, University of Sri Jayewardenepura, Sri Lanka
}

\begin{abstract}
The archetype of 'Bitch-goddess' is a literary concept which is often read and depicted as entailing negative connotations. It is researched in relation to twentieth century literary work, which depicts feminine and powerful female characters. This approach fosters reading of 'Bitch-goddess' archetype in a positive light and in relation to Greek drama; a source of art, culture and history. Focusing on the two Greek dramas, Medea and Lysistrata which serve as my primary texts, I demonstrate that the afore mentioned archetype is not a form of deviance, but a form of revolutionary transgression that threatens the unbridled authority that patriarchy wields. Both dramas depict how the 'Bitch-goddess' functions in the patriarchal society as the dramas showcase the nature of the patriarchal society, in addition to the fact that they are produced in a patriarchal society. My approach is analytical and qualitative and focuses whether 'Bitch-goddess' is a 'label' that is utilized by the patriarchy to undermine the power of women with agency. Women who possess immense power and agency are labeled as 'Bitch-goddesses' and their actions which do not conform to that of normative gender roles are deemed as deviant and transgressive. Thus, the research reveals that patriarchy brands powerful and defiant women as 'Bitch-goddesses', as their transgression threatens patriarchy and challenges the absolute authority that the patriarchs possess.
\end{abstract}

Keywords: Bitch-goddess; patriarchy; transgression; revolutionary

\section{Introduction}

Gender stereotypes/archetypes have given rise to many controversial debates, and its relevance and significance surpass temporal limitations. 'Bitch-goddess' is one such gender stereotype, which has been read with negative connotations, and such reading raises little or no suspicion in a largely male-dominated culture. Literature, a domain monopolized by males rarely documents about living, breathing female characters. The tales of powerful women are written as cautionary tales and such stories serve the agenda of patriarchy by curtailing the immense potential females encapsulate within them. Branding of strong and revolutionary female characters using derogatory labels such as Bitch-goddess' is another strategic measure the patriarchy uses to conceal their inability and powerlessness in the face of such transgressive women. This study is executed with three objectives namely; examining whether being a 'Bitch-goddess' grants women the opportunity to transgress the social norms dictated by the patriarchy, investigating whether branding a woman as a 'Bitch-goddess' is a strategy that is utilized by the patriarchy to veil its incapability, and exploring whether the archetype of 'Bitchgoddess' is a patriarchal construct which is used to undermine the power of women with agency.

My argument is theoretically substantiated by Russ's (1995) concept of 'Bitch-goddess' which is presented in the article What Can A Heroin Do? or Why Women Can't Write. I chose this as my primary theory because, it is where I derived the definition of 'Bitch-goddess'. According to Russ (1995) 'Bitch-goddess' is “[an] impossible "wom[a]n", a figure who is beautiful, irresistible, ruthless but fascinating, fascinating because she is somehow cheap or contemptible, who [...] destroys men by her indifference and who [...] destroys men actively, [...]” (p.202). I have also incorporated Allan G. Johnson's Gender Knot: Unravelling Our Patriarchal Legacy as a secondary theory for my research, as my research scrutinizes the archetype of 'Bitch-goddess' in relation to the patriarchal society. 


\section{Discussion}

In classical literature we find similar gender stereotypes and or characters who fit into these gender stereotypes. Charles Seltman accounts to this notion by stating that "[o]nly adults could create and understand the characters of Clytaemnestra and Electra, Antigone and ... Alcestis, Medea..., because there were living Athenian women of whom these characters were types" (Seltman, 1955). The seventh poem of Semonides of Amorgos is also a fine example to depict characterization of women in Ancient Greece. "This seventh-century satire on women refers various types of women to corresponding animals such as the sow, vixen, bitch, and so on" (Walcot, 1984). This satire provides evidence for the existence of so called 'bitchy' women even during the classical period. Clytaemnestra, Medea, and Deianeira are some examples of 'Bitch-goddesses' from classical Literature.

It is interesting to note that all the 'Bitch-goddess' characters from Medea and Clytaemnestra to Daisy Buchanan and Margot Macomber are powerful, dominant, defiant, strong and revolutionary. These traits make them devouring, and dangerous. Russ (1995), states that these archetypes are 'public roles' of women at their 'worst' and "they are gorgeous Cloudcuckooland fantasies about what men want, hate, or fear" (p.81). Dolores Schmidt's (1971) definition; "The bitch is no laughing matter; she is a man-eater", supports the above claim meanwhile implying the underlying meaning, that 'Bitch-goddesses' are capable of posing a threat not only to men particular, but to the whole patriarchy. This results in the rejection towards such women. This refutation is quite apt to be read as an unwillingness to accept the 'power' wielded by women with agency.

In The Second Sex Beauvoir (1974) argues that:

"[...] Society being codified by men, decrees that woman is inferior: she can do away with this inferiority only by destroying the male's superiority. She sets about mutilating, dominating man, she contradicts him, she denies his truth and his values [...] All oppression creates a state of war. And this is no exception".

The above quoted lines explain why defiant women are deemed as 'Bitch-goddesses'. Once you transgress set boundaries, you are no longer one with the rest, but an 'outsider'. The same ill fate befalls upon the women who try to assert their position by 'destroying male superiority' (Beauvoir, 1974). They are not only rejected, but also branded/ labeled as 'Bitch-goddesses' and they are to live with that 'insult'. Luce Irigaray (1991) perceives these women who are seen as malevolent as women who refuse to be 'use-value to men'. This perception entails a revolutionary take as 'Bitch-goddesses' defy the accepted 'culture' and 'norms'.

When one observes this incident closely, he/she realizes that the whole act of laying the accusation on women is problematic. Patriarchy, which is vigilant about its safety, takes precautions to eliminate any threat that come across its way. The branding/labeling of defiant and powerful women also can be one such precautionary act that patriarchy takes to eradicate the possible threats.

\section{Bitch-goddess' in 'Oikos' (oĩkos)}

Women were always professed as the 'weaker sex', which needed constant guidance and protection from males. The same reason results in initiating the three 'safety-valves' as brought out by Walcot (1984), "which served to safeguard the integrity of women and so to ease the obligation on the part of male relatives" by the Athenian society (p.37). The third and most outstanding 'safety-valve' is "the confinement of women to the home, a restriction on a woman's freedom of action" (Walcot, 1984, p.38). This precautionary act is named a 'safetyvalve' mainly because, men; the agents of patriarchy think that women are incapable of taking care of themselves. They are frightened that; women's actions would cause them some danger, and this unsettle them from within.

Women were expected to play the 'angels in the house' and her role was to be strictly within the confinements of the domestic sphere. The positive energies that are encapsulated within women are wasted, given the fact that women are entrusted only with domestic responsibilities. She is expected to perform the roles of a 'good' wife, 
mother and a housewife. Her confinement to the domestic sphere, censors her capabilities and this in fact benefits men, because they are not being challenged by the fraction whom they consider as the 'fair defect' but, who in reality are more competent, achieving, domineering and boisterous than men. In such a context, women who are eloquent, demanding and powerful are deemed as 'Bitch-goddesses' and they are loathed and despised. In The Laugh of the Medusa Hélène Cixous (1980) highlights the strength in women to break the 'feminine silence' as the most revolutionary aspect pertaining to 'bitches'. This is because, as Schmidt (1971) points out that the agents of patriarchy believe that, "women are not equipped for civilization, [and] they are at their best when natural, instinctive, accepting anatomical destiny and total dependency" (p.904). Such expectations about women, and acceptance of those expectations as norms and mores by women facilitate the existence of patriarchy, the very establishment that thwarts the capabilities of women in order to ensure their existence. Schmidt (1971) espouses the notion that "The [g]reat American [b]itch of [twentieth century] fiction, [...], is more myth than reality, a fabrication used to maintain the status quo" (p.904). This statement suggests how the patriarchy misuses the 'Bitch-goddess' archetype to propagate their patriarchal agenda. The revolutionizing power wielded by 'Bitch-goddesses' is manifested as foul play. Manipulation is the core of patriarchy that eases its pathways and its dwelling process. The delusion it creates pervades the society, veiling the bitter truth that it conceals.

In a society that espouses double standards that were male-biased, infidelity was an offence from which men can easily get away with. Andromache was identified as the "legendary model of wife and mother throughout the antiquity" (Barlow, 1989, p.158) because, she tolerated Hector's infidelities. Medea does not identify herself with such submissive, meek and self-sacrificing women. She perceives women as the "most miserable of specimens!" (Euripides, 1996, p.56), because "at great expense [they] must buy a husband, [...] master to play the tyrant with [their] bodies" (Euripides, 1996, p.56). She explains further that the divorce is not an option that is open for women, "[f]or divorce brings disgrace on a woman" (Euripides, 1996, p.56). Medea's criticism about the institution of marriage, not only reveals the existent mores of that society pertaining to marriage, but also her autonomous nature, which makes her a woman who does not believe in the 'ideal' role of a woman. Her actions draw immense attention as they are 'ground-breaking' even during the contemporary times.

Seltman (1955) states that, "[t]he woman who held in [...] the deepest respect, regard, trust, and affection of a man was usually his wife, the mother of his children, the keeper and manager [of the household]" (p. 120), demarcating the boundaries within which women should showcase their excellence. Medea is a woman who despises the normative gender role by upsetting the tranquility of her domestic sphere, in her attempt of bringing justice for herself. The above notion and her anger and fury are well manifested in Medea's following utterances:

"When a man becomes dissatisfied with married life, he goes outdoors and finds relief for his frustrations. But we are bound to love one partner and look no further. They say we live sheltered lives in the home, free from danger, while they wield their spears in battle- what fools they are! I would rather face the enemy three times over than bear a child once". (Euripides, 1996, p.57)

Men try to place themselves on a pedestal and treat themselves as divinity by showing that their deeds are par excellence. Medea questions the status quo and her inquiries highlight the blunt notions that are cultivated in the society. She even questions Creon's verdict about her banishment. Her defiance of what is accepted as the 'proper womanly conduct', results in branding her as a 'Bitch-goddess' and she becomes one because, she '[...] rudely violate[s] conceptions of proper sex role behavior" (Freeman, 1969, p.2). The real question is what is 'proper sex role behavior'? and who decides what is the accepted conduct?

Calonice in Lysistrata, states that, "[i]t's not so easy for a wife to get out of the house, [...]. They'll all be hanging round their husbands, waking up the servants, putting the baby to sleep or washing and feeding it" (Aristophanes, 2002, p.141) unfolding the domestic chores of women. In addition to being confined to the domestic sphere, "[w]omen have lived in a separate women's quarter in the most remote and protected part of the house" (Salisbury, 2001, p.140). This account highlighted by Salisbury (2001) demonstrates the excessive limitations that chained Grecian women. Lysistrata steps out of this so called 'safety zone' to fight for a 
common cause, saving Greece by ending the Peloponnesian war. Lysistrata's proposal stands out as controversial and revolutionary, for it is men who are considered as the 'saviours of the nation' and women are expected to manage the household, while bearing sons for the better good of the country. Their involvement in the state affairs is not tolerated by men. The society admired women like Alcestis and abhorred women such as Lysistrata and Medea because, patriarchy esteemed sacrifice, loyalty and commitment of women, as those traits facilitate the existence of patriarchy. As patriarchy is "[...] male identified and male centered, women and the work they do tend to be devalued, if not made invisible [...]" (Johnson, 2014, p.15). In such a society, women are devalued and ill-treated, irrespective of the fact whether they fulfill their normative duties or contravene those duties. This is why French (1985), (as cited in Johnson, 2014) argues that, “[...] historically women's oppression has amounted to a form of slavery" (p.15).

As Salisbury (2001) unveils, "[t]he purpose of marriage [in Greek society] was procreation [...]" and "[the] society [has] accepted homosexual relationships and male sexuality with slaves and prostitutes, [...]" (p.141). These lines show the sexual freedom enjoyed by men, while laying emphasis on the fact that they had dominance even in sexual relationships. These 'absolute' patriarchs only sought for women who were sexually inexperienced. In such a society, tabling a 'taboo' topic for women and deciding on a sexual boycott are revolutionary steps that threaten patriarchy.

For patriarchy; “[...] control, strength, competitiveness, toughness, coolness under pressure, logic, forcefulness, decisiveness, rationality, autonomy, self-sufficiency, and control over any emotion [...]” (Johnson, 2014, p.7) were in the male domain and those were the traits that demarcated their 'superior position'. Men discouraged cultivation of such traits in women in order to ensure their safety. In contrast, women were expected to possess qualities such as, "cooperation, mutuality, equality, sharing, empathy, compassion, caring, vulnerability, a readiness to negotiate and compromise, emotional expressiveness [...]" (Johnson, 2014, p.7). Medea is well equipped with the traits that were there absolutely for men. Her intellect, rational and logical thinking are well manifested from the way she plots and executes her plan to punish everyone who has wronged her. According to Russ (1995), "[t]he woman who becomes hard [...], who competes with men, finally becomes [...] a bitch[goddess]". This is why Medea is portrayed as a 'Bitch-goddess' and she readily accepts herself to be one with the given epithet, that makes her actions rebelious. First, Medea manipulates Creon by assuring him that, she "will yield the victory to stronger opponents" (Euripides, 1996, p.58). She outwits Creon, who is suspicious of her because, he is aware that he cannot defend himself from a woman who is "clever and controls her tongue" (Euripides, 1996, p.59). By doing so she buys more time for her to device her scheme. Walcot (1984) questions, "[w]as it because the Athenian male thought women weak and feeble and so held them in contempt? [o]r was it because he found women to be strong and effective and so regarded them with fear?" (p. 39) in his attempt to find as to why men were suspicious of women. In Medea, both Creon and Jason suspect Medea, and this is because they recognize her potential. Creon's acceptance that "[he] fear[s] [Medea]" (Euripides, 1996, p.58) assures that he is aware that Medea is capable of great feat. Similar mastery can be seen in Lysistrata's plot, where she takes the extreme measure of initiating a sex strike to make sure that men are made to surrender themselves. The act of seizing the Acropolis is a clever choice as it is a stronghold of men, where "[men] have bottomless fund o' money" (Aristophanes, 2002, p.147).

In a patrilineal society, male children are of utmost importance. Medea's willingness to forgive Jason for desiring a new bride, "[...] if [Jason] still [...] had no sons," (Euripides, 1996, p.63) is a strong indication of the fact that male children were celebrated. The fact that Aegeus has consulted the Delphic oracle to "ask how [he] might father [an] offspring" (Euripides, 1996, p.68) also depicts how much they yearn to have a male child, for birth of a son is the accomplishment of marital life of any ordinary man. It bears greater significance when it comes to the royal family as the throne passes from father to son. This is why Medea decides to "kill [her] own children" (Euripides, 1996, p.71), as it is the most effective way of inflicting immense pain upon Jason. Mitchell-Boyask (2008) espouses similar notions in his introduction to Medea. This filicide is an act which unsettles the very establishment of the patriarchal society, as it symbolically represents the uprooting of the patriarchal society. By murdering her sons, Medea not only violates the role of a mother but also the duties of a 'good' wife. The way in which Medea transgresses the boundaries of the domestic sphere, appears as a shock to 
everyone. She makes sure that Creon and his daughter are also subjected to punishment as she determined earlier, saying that, she "will make corpses of three of [her] enemies, father, daughter and husband [...]" (Euripides, 1996, p.60).

In Lysistrata, women take over the power to nullify the authority wielded by the patriarchy. The significance of the male child is highlighted in this drama as well. Lysistrata states that, "[w]e've contributed to it twice over and more. For one thing we've given you sons, and then had to send them off to fight" (Aristophanes, 2002, p.164) emphasizing the fact that women have a right to make decisions as much as the men do.

Medea's actions reverse the existing conceptions about male superiority, and guarantee that, "women [shall never] endure the burden of ill-repute" (Euripides, 1996, p.61). After initiating justice, Medea appears triumphantly on a dragon driven chariot, ready to fly to Athens as she was promised shelter by King Aegeus, in exchange for "put[ting] a stop to [Aegeus's] childlessness" (Euripides, 1996, p.70). By refusing to let Jason touch his children's dead bodies for the last time, Medea ensures that Jason is experiencing the same despair and helplessness that she experienced at the beginning of the play. Jason's lamentation, "Zeus, do you hear how I am rejected, what injury she does me, [...]" (Euripides, 1996, p.87) reveals the reversal of the power positions. Jason's emasculation, loss of authority and dignity add to the loss of his kindreds.

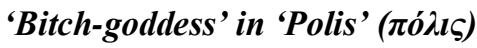

The socio-political makeup of the society grants unparalleled superiority and undisputed authority to males since the history dates to the times unknown. Men operated the state and national functions in the public sphere while functioning as the heads of the domestic sphere. Johnson (2014) claims that, "[p]atriarchy is male dominated [and thus,] positions of authority-political, economic, legal, religious, educational, military, domestic - are generally reserved for men" (p.6). His claim asserts the fact that power and authority are associated with masculinity. Magistrate (one of the ten probouloi) in Lysistrata, Philocleon and the chorus in Wasps, Sophocles' Ajax and Euripides' Heracles are few classical examples of men who excelled in the domains of government, law and warfare. According to Katz (1992), "[the] birthright constitutes men as possessing a natural political right" (p.82), which makes them eligible to govern the 'polis'. Their 'maleness' grants them unconditional freedom to engage in any aspect they aspire, simply owing to their privileged position. Therefore, they postulate that "power looks sexy on men but not on women" (Johnson, 2014, p.8). "Patriarchal power or the government of women by men" (Pateman, 1989, p.2), thoroughly abstain any kind of female involvement in 'polis', as they "[...] stress [...] the importance of the family and of women's role within it as nurturers and continuers of the race [...]" (Lefkowitz, 1985, p.218).

Patriarchy functions with "[...] an obsession with control as a core value around which social and personal life are organized" (Johnson, 2014, p.14). Therefore, men resolve to dominate, to ensure their privileged position is felt over others. Daly (1973) (as cited in Johnson, 2014) argues that men "[...] having God identified with them, $[\ldots]$ further reinforces the position of women as 'other' or the secondary sex in the society and the legitimacy of men's claim to privilege and dominance" (p.10).

Due to the immense power wielded by men, women were confined to an 'inferior' and 'subordinate' position. Most of the women accepted the gender role assigned to them and were loyal. Women such as Alcmena were respected and celebrated throughout the history as they consciously or unconsciously aid the sustenance of patriarchy. According to Lefkowitz (1985):

"heroic age is brought to an end by the three daughters of Tyndareus, "twice and thrice married and leavers of husbands": Timandre who left her husband Echemus for Phyleus, Clytemnestra who "after she deserted her husband Agamemnon slept with Aegisthus and chose a worse husband, and then Helen disgraced the bed of fair-haired Menelaus". (p.214)

Women mentioned above were perceived as 'wicked' and 'bitchy' as they have not shown any respect or loyalty to their husbands, which is in fact a major offence in a patriarchal society. Lysistrata is one such woman who 
transgressed the normative role and stepped into the 'polis' as she wills the greater good of the society. "Why such women arise from time to time?" is a major question that should necessarily be answered. The major reason is none other than the inadequacy and incapability of men who carry out the state functions. Lysistrata's justification, '[...] every time two men meet [...], what do they say? 'Isn't there a man in the country?' And the answer comes, 'Not one'. That's why we women got together and decided to unite and save Greece" (Aristophanes, 2002, p.161), clearly manifests the above claim. Though men are at fault, they do not want to accept their inadequacy. To defend themselves, they seek the assistance of the 'female cultural identity' which again is a fabrication of the patriarchy. "[T]he more powerful a woman is under patriarchy, the more 'unsexed' she becomes in the eyes of others as her female cultural identity recedes beneath the mantle of male-identified power and the masculine images associated with it" (p.8) states Johnson (2014) describing the repercussions that a woman has to face when she assumes a power position.

According to Foley (1982), "the female intrusion [to the polis] poses threats as grave as the masculine misbehavior that provoked it" (p.5). This notion is nullified by Lysistrata's acts of bringing about peace and uniting Greece, deeds that benefit the 'Panhellenic' world. Men boast about themselves and try to indicate that, the deeds they are engaged in are the most noble of professions. Among the things that they have taken charge of, war is a horrendous deed. Irrational, illogical and egoistic impulses of men keep them engaged in war, causing irreparable damage to the entire society. To avert the danger and unwanted wastage of human lives, money and other resources, the so called "sub-human creatures" (Aristophanes, 2002, p.159) come to the fore front. Lysistrata's utterances, "[w]e want to keep the money safe and stop you from waging war" (Aristophanes, 2002, p.159) unfold their motive behind the act of seizing the Acropolis. When the magistrate questions "[w] hat have you ever done for the war effort?" Lysistrata answers "[...] [w]e've contributed to it twice over and more. For one thing, we've given you sons, and then had to send them off to fight" (Aristophanes, 2002, p.164).

As men are blinded by their domineering attitude, they are engulfed in the false belief that, women are ignorant of men's actions. In reality, "[women] knew everything [men] were up to. [They get to] hear at home about some major political blunder of [men]" (Aristophanes, 2002, p.161). When women inquire about the decisions that the men have taken, they simply reply '[s]hut up and mind your own business!' (Aristophanes, 2002, p.161), in the most scornful manner. Men's act of denying admittance for women to engage in the 'polis' portrays the fact that, women were not recognized as 'citizens' who naturally possess the right to question the actions of the state and also to know whether the decisions ensure a favourable living condition. This most thoughtful act of devising a method to bring about peace is seen as a betrayal against patriarchy and their discontent is projected through the lines, "[i]ncredible! [i]mpossible! / [o]ur women, if you please! / [w]e've kept and fed within our homes/ [a] pestilent disease!" (Aristophanes, 2002, p.150). To veil their guilt of being impotent, men accuse that "women venturing to prate / [o]f war and arms and high affairs of state!" (Aristophanes, 2002, p.165) are 'disgraceful'. Johnson (2014) explains this situation stating that, "[w]e confuse systems with individuals, personalize patriarchy, and get stuck in cycles of guilt and blame" (p.193).

Aristophanes' Lysistrata presents women who question the status quo. Stratyllis questions, “[...] [w]here's all the gold/ [their ancestors] took from Persian foes of old?" (Aristophanes, 2002, p.167) and accuses men of squandering the wealth and "liv[ing] instead on tax" (Aristophanes, 2002, p.167). Before levelling accusations against men, she confirms that "[her] gender has no bearing on the question/ [w] hether [she is] offering [men] a good suggestion. / [as long as she is] a full member of [the] civic club" (Aristophanes, 2002, p.166). As Johnson (2014) argues, "[...] women are supposed to be perpetually good natured, smiling, accepting, accessible, and yielding, lest they be thought of as cold, frigid bitches" (p.98) explicating why Lysistrata and her followers fall into the category of 'Bitch-goddesses'.

Connell (1995) (as cited in Lau, 2015) defines masculinity as "[...] the configuration of gender practice through which patriarchy is legitimized and women are subordinated" (p.4). Overpowering women is an essential component of masculinity, and when a reversal of power occurs, men are said to be emasculated, which is considered as the worst insult on a man. Men been overridden by women is a strong indication of their 
helplessness, and this claim is expounded through magistrate's utterance; "[y]ou, damn you, a woman with a veil on her head, order me to be silent? Gods, let me die!" (Aristophanes, 2002, p.161). The inability of men to retaliate towards women who reveal the truth while questioning the follies of men leave them with the question, "are we all castrated" (Aristophanes, 2002, p.167). "Women's potential to be like men allows women to use the simple choice of how to be as women to influence how men feel about themselves as men [...]is often attributed to women as some kind of negative personality trait-the castrating bitch" (p.187) states Johnson (2014) unfolding the reality. Medea also emasculates her husband by saying that, "[...] my tongue can utter no worse abuse against your spinelessness" (Euripides, 1996, p.62). The emphasis is laid on Jason's inability to take a proper decision and his impotence to secure his wife and family. Even though the truth makes a sound presence, as men are not willing to accept their failure, they choose "[t]he path of least resistance, [which] is to resent and blame women for what men lack, by accusing women of not being loving [...], of being manipulative, [...], selfish bitches who deserve to be punished" (Johnson, 2014, p.61).

Gilligan (1982) (as cited in Gabriel 1992) "proposes a [...] binary model of moral judgment in which women follow an "ethic of care" and men follow an "ethic of justice and rights"" (p.349). This notion falls in line with the idea of two separate spheres: 'oikos' and 'polis'. Medea flouts this categorization by initiating the 'ethic of justice and rights. Her concern about moral righteousness comes to light when she questions, "[o] Zeus, why is it you have given men clearways of testing whether gold is counterfeit but, when it comes to men, the body carries no stamp of nature for distinguishing bad from good?" (Euripides, 1996, p.64). She despises Jason because, he breached the oath vowed upon the names of the god. Her displeasure is manifested through the following lines, "[g]one is the trust to be placed in oaths; I cannot discover if you think that the gods you swore by then have lost their sovereignty or that new laws these days are prescribed for men, [...]" (Euripides, 1996, p.63). His "lack of principle[s]" (Euripides, 1996, p.63) and shrewd nature of ensuring his stability and safety at the cost of anything is not approved by Medea who is genuine and self-confident in her endeavours.

Medea's inclination towards establishing justice is a salient factor that even surpasses her familial relationships. She accentuates the political bond between Jason and herself by stating that, "[Jason] owes a life to [her]," (Euripides, 1996, p.63). Her patronage without which Jason's political enterprise of bringing back the golden fleece, would be an utter failure. Though her reasons are just enough for her to seek justice, "[...] Jason undermin[es] it by genderizing, domesticating, and privatizing her protest. Jason presents Medea as "the problem"'” (Gabriel, 1992, p.358). This trivialization of Medea's retaliation showcases the threat that Medea poses. "[...] Jason and Creon make every effort to depoliticize the protest and use gender categories to conceal [...]" (Gabriel, 1992, p.348) Medea's political assertion. This depicts how the 'ethic of justice and right' that should be practiced by men is flouted by them for their own benefit.

One trait that all the Greek heroes have in common is the 'heroic code'. "[...] [T] he duty of a hero to benefit those connected to him by blood or friendship, [...], his philoi, and to harm his foes or echthroi" (Bongie, 1977, p.33) is what is known and practiced as the "heroic code'. This was adopted by most renowned heroes such as Ajax, Heracles and Achilles. Medea's heroic deed is outstanding as her philoi, Jason is her worst enemy as he betrayed her. Nurse's utterance, "I pray her victims are enemies, not those who love her!" (Euripides, 1996, p.53) which appear at the very beginning of the play, foreshadows Medea's latter deeds. As all the other heroes, Medea is "concerned with honour, with glory [and about] humiliation by her enemies" (Barlow, 1989, p. 161). Jason dishonoured Medea by breaking his vows to Medea and to the gods on whom he swore his matrimony to Medea. Her determination to avenge this blunder is such that she states, "[n]ot one of them will live to boast of vexing my heart, [...] [n]ow is [my] courage put to the test!” (Euripides, 1996, p. 61).

Though Medea has no allies to assist her, she manages to avenge everyone who has insulted her, all on her own. As Bongie (1977) analyses "Medea has a negative aim inspired by the same values, namely, not to lose the honour she had, not to be disgraced and revealed as helpless in the course of events" (p.31). All the heroes must make great sacrifices to accomplish their heroic deeds. Bongie (1977) declares that, "Medea is probably the most genuinely "heroic" figure on the Greek stage in that she shows greater determination in the achievement of her ends and makes greater sacrifices to her honour than does any other tragic figure [, as] Medea sacrifices her own children" (p.32). Medea is known for her cleverness. The plan she concocts is well thought out, as she 
attacks the most susceptible aspect of the enemy. She understands the most effective way to avenge the disgrace brought onto her by Creon and Jason is to harm their children.

Though women are suppressed and silenced repeatedly to assure the continuation of patriarchy, women never stop proving that they are capable of every endeavour. They would not hesitate to take up any challenge. Therefore, Medea opted to initiate social order and justice, and why Lysistrata and her followers opted to save Greece by ending the brutal war. None of these deeds are appreciated, instead they brand women who engage in such deeds as bitches, as "[a] woman perceived as controlling a man is typically labeled a castrating bitch or a ball buster" (Johnson, 2014, p.14). 'Bitch-goddesses' must swim against the current of existing patriarchal system to establish themselves in the society. Even though this journey is embedded with great difficulties, women like Medea and Lysistrata have proven themselves victorious. Their ability to traverse in an atmosphere which is inconducive towards them attest their capability. In this chapter we see women who carve their own niche, without aspiring to achieve "[...] goals [...] shaped by social systems [patriarchy] which deny them ready access to the social privilege, authority, and esteem enjoyed by a majority of men" (Rosaldo, 1980, p.395).

\section{Tyranny of Patriarchy}

As Johnson (2014) describes, patriarchy "[...] promotes male privilege by being male dominated, male identified, and male centered [...] and involve[ing] as one of its key aspects the oppression of women" (p.5-6). The misuse of the excessive power wielded by patriarchy is a common occurrence, that would easily pass unnoticed as the agents of patriarchy use tactics to veil them. Refusing to admit and to submit to the patriarchal authority would result in receiving unfortunate consequences. "Daphne [who] refused to have sexual relations with Apollo and ended up fixed in one place - as a laurel tree" (Lefkowitz, 1985, p.210), appears as a mythical example for the above claim.

The unrivalled power that patriarchy wields, cannot stand as a shield that conceals its numerous flaws. As Gabriel (1992) points out "[a]bsence of resistance, [...] does not necessarily mean women's lack of awareness [...]" (p.348). Therefore, however much patriarchy tries to keep their faults unexposed, they are pretty much obvious. In Lysistrata, Aristophanes portrays the ineffectiveness of patriarchy as the authoritative body that oversees the state and political functions. The senile and unproductive nature of the patriarchy stands as a threat to the whole society as the state functions are at a stand-still owing to this reason. Therefore, women take up the responsibility of the state functions by seizing the Acropolis and by "renounc[ing] sex" (Aristophanes, 2002, p.145). "[...] [E]very time two men meet [...], what do they say? 'Isn't there a man in the country?' And the answer comes, 'Not one'. That's why we women got together and decided to unite and save Greece" (Aristophanes, 2002, p.161) states Lysistrata explicating why womenfolk had to unite in order to bring about peace. War brings glory and fame to men irrespective of the fact whether they die or become victorious in war, and this is why men engage in the pursuit of war. Their obsession with war had severe consequences on the society, as it sucked out all the monetary funds and valuable human lives. Though women had "[...] given [men] sons, and then had [...] [sent] them off to fight" (Aristophanes, 2002, p.164), the inevitable danger that their sons encounter, remain as a burden that weigh their hearts. This results in initiating a sex strike to avert the untimely deaths that would befall upon them. To "[...] keep the money safe and stop [men] from waging war" (Aristophanes, 2002, p.159) they seize the Acropolis and cut off the monetary funds.

Euripides also brings out the irresponsible manner in which men operate in both public and domestic spheres, through the characters of Jason and Creon. Jason appears to be a feeble and selfish character throughout the play. He is unable to stand on his own and thus, he utilizes women to pave his path of success. Apollonius' Argonautica projects how Jason was limitlessly aided by Medea in his pursuit of bringing back the golden fleece to claim his patrimony. As Mitchell-Boyask (2007) brings forth, it is Medea who:

“[...] anointed [Jason's] body with a protective oil against the bulls' fire and then put the guardian serpent to sleep. After escaping with the fleece, Medea [...] killed her young brother, chopping his body to pieces and throwing them overboard in order to slow the pursuing fleet". (p. xxiv) 
Thus, it is evident that though Jason is celebrated as a hero who succeeded in his political enterprise, it is Medea who eased his path and helped him throughout in fulfilling Jason's objective of reclaiming the throne from King Peleus. The social position and the prestige he enjoy is all because of Medea, and this is why she boldly states that, "[Jason] owe [his] life to [her]" (Euripides, 1996, p.62-63). In order to establish his position in Corinth, he takes the hand of the Corinthian princess. In the play he shamelessly states his objective behind taking a new bride as follows:

"[He] wanted $[\ldots]$ to live comfortably and not go without anything, [...] [and] also wanted to raise [his] sons in a manner worthy of [his] house and, by producing brothers for [his] sons by [Medea], to put them on an equal footing [...] by joining [the] two families into one, to ensure [his] prosperity". (Euripides, 1996, p.65)

He not only takes advantage of the new matrimony but also proves to be an inadequate husband to his first wife, thus showcasing his double failure to cater to the attributes of a conventional man in a patriarchal society both as an agent of the state and the head of the family. His inability to secure his wife and children from banishment adds to his failure.

Gabriel (1992) writes that, "[i]n ancient Greece, the gods are the highest authority and the ultimate protectors of justice. [...] [And] [o]aths in the name of the gods are made to bind people within and across political systems" (p.352). Breaching these vows evoke the wrath of gods, which can be lethal at times. Aegeus not having "[...] children because some god has willed it so" (Euripides, 1996, p.68) is a good indicator of the above argument. In Medea, Jason also breaches his oath to Medea. As Gabriel (1992) argues, "Jason is a man who defies the gods and brings a curse on himself and his children when he breaks his oath to Medea" (p. 352-353). This line of thinking lays the fault of the death of the children in Jason's hands, again manifesting his failure as a father.

Similarly, Creon also flouts socially accepted norms and proves himself to be at fault. As the king of Corinth, Creon not only violates the code of hospitality by ordering banishment to Medea and her children, but also violates the way in which a man should treat a woman. Lattimore (1955) (as cited in Gabriel, 1992) argues that, Creon violates the rule of "'the nonabuse of power against those over whom one has power" (p.353-354) by flouting the code of hospitality. His words, "I order you to leave this land and become an exile, [...] I fear you $[\ldots]$, I hear that you are making threats, [...] to [...] harm the three of us" (Euripides, 1996, p.57-58) unfold the fact that he banishes Medea, purely out of personal motives. It is also obvious that there is no justifiable reason for him to punish Medea, and the only notable reason is that as Medea is the wife of Jason, she might pose a threat. Ordering banishment basing on suspicion manifests how men misuse their power, to harm the powerless.

Both Jason and Creon are driven by their personal motives. They do not act as agents of social order, rather they disrupt it. In contrast, Medea tries to establish social order in the Corinthian society. For her, personal bonds are immaterial. This is why she does not hesitate to bring havoc to her husband's life by murdering her own children. The chorus remarks, "[u]phill flow the waters of sacred rivers; nature and all things are overturned" (Euripides, 1996, p.61), describing the difficulty with which Medea re-establishes the order and justice, while ensuring that, "[n]o more shall [...] women endure the burden of ill-repute" (Euripides, 1996, p.61). Her protest is difficult as she has to stand against injustice all alone. Her conduct appears far more superior than that of the male patriarchs in the play, as she "[...] appears above the stage in a chariot drawn by dragons" (Euripides, 1996, p.84). Her appearance high up on the skene indicates that the gods approve of her actions and that she is the higher authority who establishes social order.

Johnson (2014) says that, "[...] male dominance creates power differences between men and women" while "promot[ing] the idea that men are superior to women" (p.6). Patriarchy is a structural prison that manipulates the society, blinded by the motive of safeguarding its power and the superior position. It inscribes the maleoriented values in the minds of the people by creating a 'male identified culture'. This fabrication serves as the medium through which their actions are justified. In Medea, Jason accuses Medea stating that, "[n]ot a woman in Greece today would ever have dared such a thing" (Euripides, 1996, p.85), to show that Medea is at fault, so that he can turn the whole society against Medea. Jason at no point declares the true reason that prompted Medea's reaction. He takes no effort to learn that either, and instead he postulates that Medea acted out of sexual 
jealousy, so that he can conveniently evade the scene by falsely accusing Medea. He carefully pulls the strings to make his false accusations to seem real.

Similarly, in Lysistrata, the magistrate reprimands women to show that they have crossed the boundaries by intruding into the 'polis'. His accusation "[...] the same old story-the unbridled licentiousness of the female sex displaying itself" (Aristophanes, 2002, p.156), is a strong indictment that would make Lysistrata and her fellow women to appear as traitors. It is the nature of patriarchy to implement and withdraw rules and regulations according to their benefit. Johnson's (2014) explanation about the derogatory term 'bitch' is a fine example that supports the above claim. He states that, "[t]he bitch was Artemis-Diana, goddess of the hunt, most often associated with the dogs who accompanied her" (p.38). However, this "[...] word has transformed from a positive cultural image of female power, independence, and dignity to an insult or a shadow of its former self, $[\ldots]$ " (p.38). This unbelievable transformation of the meaning of the word explicates the manipulative power that men possess.

\section{Conclusion}

In conclusion, men are unable to stand the transgression and which comes in the form of resistance. As patriarchy is threatened by such powerful and revolutionary women who would not bow down to the authority of men, men view them with contempt and drown them with insults. They manipulate the society in such a way that the society unquestioningly believes them and venerates them for their 'superiority'. This 'superiority is assured by condemning women with agency as 'inferior', 'weaker sex'. To ensure the sustenance of their authority and the patriarchy, patriarchal society 'brands'/ 'labels' women with power, agency and revolutionary spirit as 'Bitch-goddesses'. This strategy serves as the means through which their impotence is veiled from the eyes of the society.

\section{References}

Aguiar, S. A. (2001). The Bitch Is Back: Wicked Women in Literature. Southern Illinois University Press.

Aristophanes. (2002). Lysistrata and other plays (Revised Edition ed.). Penguin.

Barlow, S. (1989). Stereotype and reversal in Euripides' 'Medea'. Greece \& Rome, 36(2), 158-171.

Bongie, E. B. (1977). Heroic elements in the Medea of Euripides. Transactions of the American Philological association, 107, 22-56.

Cixous, Hélène. "The Laugh of the Medusa." 1975. New French Feminisms. Ed. Elaine Marks and Isabel de Courtivren. Amherst: U of Massachusetts P, 1980. $237-54$.

de Beauvoir, S. (1949). The second sex (C. Borde \& S. Malovany-Chevallier, Trans.). New York: Vintage Books.

Euripides. (1996). Medea and other plays (J. Davie, Trans.). Penguin.

Foley, H. (1982). The "female intruder" reconsidered: Women in Aristophanes' Lysistrata and Ecclesiazusae. Classical Philology,77(1), 1-21.

Freeman, J. (n.d.). The bitch manifesto. Retrieved March 14, 2018, from http://www.jofreeman.com/joreen/bitch.htm

Gabriel, A. (1992). Living with Medea and thinking after Freud: Greek drama, gender, and concealments. Cultural Anthropology, 7(3), 346-373.

Irigaray, Luce. "This Sex Which Is Not One." 1977. Feminisms: An Anthology of Literary Theory and Criticism. Ed. Robyn R. Warhol and Diane Price Herndl. New Brunswick: Rutgers UP, 1991. 350-56.

Johnson, A. G. (2014). Gender knot: unravelling our patriarchal legacy (Third ed.). Philadelphia: temple university press.

Katz, M. (1992). Ideology and "the status of women" in ancient Greece. History and Theory, 31(4), 70-97. 
Lau, S. (2015). Unmasking 'sidekick' masculinity: A qualitative investigation of how Asian-American males view emasculating stereotypes in U.S. media (Doctoral dissertation, 2015). London: Media@LSE, London School of Economics and Political Science ('LSE').

Lefkowitz, M. (1985). Women in Greek myth. The American Scholar, 54(2), 207-219.

Mitchell-Boyask, R. (2007). Euripides Alcestis, Medea, Hippolytus (D. A. Svarlien, Trans.). Hackett Publishing Company, Inc.

Mitchell-Boyask, R. (2008). Euripides Medea (D. A. Svarlien, Trans.). Hackett Publishing Company, Inc.

Pateman, C. (1989). The disorder of women: Democracy, feminism, and political theory. Stanford University Press.

Rabinowitz, N. S. (2008). Greek tragedy. Malden, MA: Blackwell.

Rosaldo, M. Z. (1980). The use and abuse of anthropology: Reflections on feminism and cross-cultural understanding. Signs, 5(3), 389-417.

Russ, J. (1995). To write like a woman: essays in feminism and science fiction. Bloomington: Indiana University Press.

Salisbury, J. E. (2010). Encyclopedia of women in the ancient world. Santa Barbara, CA: ABC-CLIO.

Schmidt, D. (1971). The great American bitch. College English, 32(8), 900-905.

Seltman, C. (1955). The status of women in Athens. Greece \& Rome, 2(3), 119-124.

Shaw, M. (1975). The female intruder: Women in fifth-century drama. Classical Philology, 70(4), 255-266.

Storey, I. C., \& Allan, A. (2014). A guide to ancient Greek drama. Chichester, West Sussex, UK: Wiley Blackwell.

Walcot, P. (1984). Greek attitudes towards women: The mythological evidence. Greece \& Rome, 31(1), 37-47. 